\title{
Problematika Pendidikan Agama Islam pada Anak dalam Keluarga Perkawinan Beda Agama di Caturtunggal Depok Sleman Yogyakarta
}

\author{
Muhammad Yusuf ${ }^{1}$, Ani Susilawati ${ }^{2}$, Aprezo Pardodi Maba ${ }^{3}$ \\ ${ }^{1}$ Institut Agama Islam Ma'arif NU (IAIMNU) Metro Lampung, ${ }^{2}$ IAIN Metro Lampung \\ ${ }^{3}$ Institut Agama Islam Ma'arif NU (IAIMNU) Metro Lampung \\ 1yusufiaimnu@gmail.com, 2anisusilawati121@gmail.com, 3 aprezopm1@ gmail.com
}

\begin{abstract}
This research is motivated by the reality of religious education for children in interfaith marriages. Where many problems are faced by parents in directing children's religious education. In order to make a focus discussion, the authors directed the study to an Islamic education. This study aims to obtain a detailed description of Islamic religious education for children in families with interfaith marriages at the Caturtunggal Depok, Sleman, Yogyakarta, as well as to discover their problems when applied Islamic education to their child. There are two stages of this study, the data collection and the data analysis. The data collection stage uses the method of observation, interviews, and documentation. While the data analysis uses a taxonomic method, an analysis carried out to explore more deeply Islamic education for children in families of interfaith marriages. The results of the study indicate that the problem in the application of Islamic education to children are parents too busy, limited religious knowledge, and parents did not make agreements on their children's religion. While the problems faced by children are confusion, inferiority, and apathy. In addition, there are positive aspects that can be taken from interfaith marriages, namely children have a basic knowledge of comparative religion and children become more tolerant in viewing religious differences.
\end{abstract}

Keywords: Interfaith Marriage, Islam, Religious Education

\begin{abstract}
Abstrak
Penelitian ini dilatarbelakangi oleh realitas pendidikan keagamaan pada anak dalam perkawinan beda agama, dimana banyak problem yang dihadapi orangtua beda agama dalam mengarahkan pendidikan keagamaan anak. Agar penelitian ini lebih fokus, peneliti mengarahkan kajian pada satu pokok pijakan yaitu pendidikan agama Islam. Penelitian ini bertujuan untuk memperoleh gambaran tentang pendidikan agama Islam pada anak usia dini dalam keluarga perkawinan beda agama di wilayah Caturtunggal Depok Sleman Yogyakarta, sekaligus mengungkap problematika pendidikan agama Islam pada anak usia dini yang dihadapi oleh orangtua dan anak dalam pernikahan beda agama. Adapun tahapan penelitian yang dilalui adalah, tahap pengumpulan data dan tahap analisis data. Tahap pengumpulan data menggunakan metode pengamatan, wawancara, dan dokumentasi. Sedangkan
\end{abstract}


tahap analisis data menggunakan metode taksonomi yaitu analisis yang dilakukan untuk menjelajahi lebih mendalam pendidikan agama Islam pada anak usia dini dalam keluarga perkawinan beda agama. Hasil penelitian menunjukkan bahwa masalah dalam penerapan pendidikan agama islam pada anak adalah orangtua terlalu sibuk dalam pekerjaannya, pengetahuan agama yang terbatas, dan orangtua beda agama yang tidak melakukan perjanjian tentang agama anak. Sedangkan problem yang dihadapi anak adalah kebingungan, kurang percaya diri, dan sikap apatis. Selain itu, ada aspek positif dapat diambil dari pernikahan beda agama yakni anak memiliki pengetahuan dasar perbandingan agama dan anak menjadi lebih toleran dalam memandang perbedaan agama.

Kata Kunci: Agama Islam, Pendidikan Agama, Perkawinan Beda Agama.

\section{Pendahuluan}

Salah satu cabang pendidikan individu yang cukup dikenal adalah pendidikan anak. Pendidikan anak dilakukan untuk menyiapkan mereka agar dapat menjadi bagian dari masyarakat yang bermanfaat dan saleh dalam kehidupannya. Dalam perspektif agama Islam, telah tersirat kewajiban untuk mendidik generasi baru.

Pendidikan agama Islam adalah pendidikan agama yang berlandaskan Islam. Pendidikan agama Islam dapat juga dimaknai sebagai usaha untuk membimbing anak didik agar setelah mereka menyelesaikan pendidikannya dapat mengerti dan mengaplikasikan ajaran agama Islam serta membuatnya sebagai pegangan hidup. ${ }^{1}$

Penulis menganggap dengan menjadikan pendidikan agama sebagai pendidikan dasar atau pendidikan awal adalah adalah salah satu kebijaksanaan, karena hal itulah yang akan menjadi panduan bagi anak dalam tahap perkembangan selanjutnya. Hal ini tidak dapat lepas dari lingkungan tempat di mana anak tinggal, lingkungan keluarga. ${ }^{2}$

Partisipasi orang tua dalam mendidik anak sangatlah krusial, karena anak merupakan amanah dari Allah SWT yang diberikan kepada orang tua dan tugas orang tua adalah membimbing dan mendidik anak sebaik mungkin agar kelak dapat menjadi seseorang yang saleh dan berakhlak mulia. Dari rumah juga anak awalnya memperoleh bekal dalam menghadapi lingkungan di luar dari lingkungan keluarga. Sehingga tugas orang tua adalah menjadi guru dan pendidik pertama dan utama bagi anak-anak mereka.

1 Ulul Ilmawanis Saadah, "Nilai-Nilai Pendidikan Islam Dalam Upacara Syukuran Ngapati Di Desa Kwayangan Kecamatan Kedungwuni Kabupaten Pekalongan" (PhD Thesis, STAIN Pekalongan, 2014).

2 Maimunah Hasan, "Pendidikan anak usia dini," Yogyakarta: Diva, 2009. 
Selain orang tua, anggota dalam keluarga besar menempati posisi penting dalam membentuk kepribadian anak secara secara utuh. ${ }^{3}$ Dalam keluarga, anak-anak memperoleh kesempatan untuk berkembang dengan meniru, menurut, mengikuti, dan mengindahkan apa yang dilakukan, dan apa yang dikatakan oleh anggota-anggota keluarga besar.

Pada dasarnya, semua lembaga baik itu formal, nonformal, ataupun informal menerima dan menyambut anak-anak dalam pendidikan mereka setelah anak dibesarkan dalam lingkungan keluarga dengan asuhan orang tua, meskipun guru di luar anggota keluarga, juga sangat berpengaruh dalam mengembangkan kompetensi anak. ${ }^{4}$ Dapat dikatakan bahwa pendidikan keluarga adalah benteng utama tempat anak-anak dibesarkan, terutama melalui pendidikan Islam. Sehingga, pola asuh orang tua sangat menentukan bagaimana anak-anak mereka dapat menghadapi pendidikan di luar lingkungan keluarga. Pola asuh sendiri merupakan proses interaksi penuh antara orangtua dan anak yang meliputi tindakan memelihara, melindungi, dan mengarahkan tingkah laku anak selama masa perkembangan serta bagaimana cara orang tua menyampaikan afeksi (perasaan) dan norma-norma atau nilai-nilai yang dipakai di masyarakat agar anak kelak dapat hidup dengan sesuai di tengah-tengah masyarakat. ${ }^{5}$

Namun demikian, kenyataan sekarang ini akulturasi budaya, bangsa, bahkan agama memicu munculnya berbagai fenomena seperti terjadinya perkawinan antar suku, bangsa, bahkan perkawinan beda agama. ${ }^{6}$ Salah satu contohnya adalah sebuah keluarga perkawinan beda agama yaitu Islam dan Kristen yang mempunyai dua orang anak dan hidup di daerah Caturtunggal. Dalam keluarga tersebut sangat nampak kedua orang tua saling tarik-menarik dalam mengarahkan pendidikan agama anak, di mana sang ayah menginginkan anaknya menjadi seorang muslim, sebaliknya yang dïnginkan sang ibu. Contoh riil yang terjadi dalam keluarga tersebut di mana pada hari minggu sang ibu mengajak anaknya sembahyang di Gereja, tapi di lain waktu ketika sang ayah berangkat ke masjid untuk menunaikan salat berjamaah anaknya pun diikutsertakan. Dari situlah

\footnotetext{
${ }^{3}$ Waharman Waharman, "Peran Orang Tua Dalam Pertumbuhan Spiritualitas Anak: Sebuah Studi Eksegetis Efesus 6: 1-4," Manna Rafflesia 4, no. 2 (2018): 116-129.

4 Arini, Aida, and Halida Umami, "Pengembangan Pembelajaran Pendidikan Agama Islam Melalui Pembelajaran Konstruktivistik Dan Sosiokultural," Indonesian Journal of Islamic Education Studies (IJIES) 2, no 2 (2019): 104-14

5 Hildha Pratiwi, "Hubungan antara Dukungan Sosial Keluarga dengan Kepuasan Perkawinan Pada Istri” (Undergraduate thesis, Surabaya, Univeristas Surabaya, 2014), http://digilib.ubaya.ac.id/pustaka.php/240188.

6 Bonar Hutapea, "Dinamika Penyesuaian Suami-Istri dalam Perkawinan Berbeda Agama (the Dynamics of Marital Adjustment in the Interfaith Marriage)," Sosio Konsepsia 16, no. 1 (2017): 101-122.
} 
terlihat ketidaksamaan orangtua dalam mengarahkan pendidikan keagamaan anak. Selain itu terlihat kecenderungan pada orangtua beda agama untuk mengajak anak menganut agama mereka, sehingga menimbulkan kebingungan pada diri anak. Fenomena semacam ini banyak ditemukan di daerah Caturtunggal, di mana kondisi masyarakatnya banyak pendatang dan masyarakatnya mudah berbaur tanpa memandang suku dan agama, sehingga sangat potensial terjadinya nikah beda agama. Dari sinilah peneliti ingin melihat lebih dekat tentang pendidikan agama Islam dalam keluarga perkawinan beda agama di daerah Caturtunggal. Sebetulnya, penelitian tentang perkawinan beda agama ini sudah cukup banyak, ${ }^{7}$ namun mereka tidak membahas bagaimana pendidikan agama Islam dalam keluarga beda agama yang menikah dengan cara Islam.

Tujuan yang ingin dicapai dalam penelitian ini adalah mengetahui gambaran pendidikan agama Islam oleh orang tua beda agama terhadap anaknya, mengungkap problem yang dihadapi orang tua beda agama dalam mengarahkan pendidikan agama Islam pada anak, dan mengungkap problem yang dihadapi anak dalam melihat perbedaan agama orang tuanya.

\section{Metode Penelitian}

Penelitian ini diarahkan untuk mendeskripsikan secara mendalam tentang pendidikan agama Islam pada anak dalam pernikahan orang tua beda agama. Penelitian ini termasuk dalam penelitian kualitatif dalam bentuk case study (studi kasus). ${ }^{8}$ Dengan penelitian ini diharapkan dapat memperoleh penghayatan, pengalaman, persepsi dari person yang menikah beda agama terhadap pendidikan agama pada anaknya. Lokasi penelitian ini dilakukan di Caturtunggal Depok Sleman, Yogyakarta. Demografi informan dapat dilihat di Tabel 1. Pengumpulan data dilakukan melalui pengamatan, wawancara, dan dokumentasi. Adapun yang diobservasi dalam penelitian ini adalah keluarga perkawinan beda agama, lingkungan tempat tinggal subjek yang diteliti, tempat anak menempuh pendidikan formal dan non-formal (sekolah dan Taman Pendidikan al-Quran).

7 Sri Wahyuni, "Kontroversi Perkawinan Beda Agama di Indonesia," Jurnal Hukum Islam, 2016; Sirman Dahwal, "Hukum perkawinan beda agama dalam teori dan praktiknya di Indonesia," 2016; Jane Makalew, "Akibat hukum dari perkawinan beda agama di Indonesia," Lex Privatum 1, no. 2 (2013); Hutapea, "Dinamika Penyesuaian Suami-Istri dalam Perkawinan Berbeda Agama (the Dynamics of Marital Adjustment in the Interfaith Marriage)."

8 Anselm Strauss dan Juliet Corbin, "Dasar-dasar penelitian kualitatif," Yogyakarta: Pustaka Pelajar, 2003. 
Pada tahap analisis data, penulis mengorganisir dan mengurutkan data ke dalam kategori dan satuan uraian, sehingga dapat ditemukan tema dan dapat dirumuskan suatu gambaran yang merepresentasikan data. ${ }^{9}$ Penulis menggunakan analisis taksonomi untuk menganalisis data, ${ }^{10}$ yaitu analisis yang dilakukan untuk menjelajahi secara mendalam pendidikan agama Islam pada anak usia dini dalam keluarga perkawinan beda agama. Teknik ini diawali dengan memfokuskan perhatian pada aspek tertentu, dalam penelitian ini yaitu keluarga perkawinan beda agama. Teknik analisis data ini dilakukan sebelum memasuki lapangan, selama di lapangan, dan setelah selesai di lapangan. Analisis data lebih difokuskan selama proses di lapangan bersamaan dengan pengumpulan data. Langkah-langkah analisis data sebagai berikut; 1) reduksi data, 2) penyajian data, dan 3) penarikan kesimpulan dan verifikasi.

\section{Hasil dan Pembahasan}

Berdasarkan hasil pengumpulan data, pada tabel 1 dapat dilihat informasi demografis informan. Informasi demografis informan ini meliputi agama, jenis kelamin, usia, status dalam keluarga, status pernikahan, dan pekerjaan. Data ini diberikan agar dapat memberikan gambaran kondisi informan pada saat dilakukan penelitian.

Tabel 1. Demografi Informan

\begin{tabular}{|c|c|c|c|c|c|c|c|c|}
\hline No & Inisial & $\begin{array}{l}\text { Kode } \\
\text { Keluarga }\end{array}$ & Agama & $\begin{array}{l}\text { Jenis } \\
\text { kelamin }\end{array}$ & Usia & $\begin{array}{l}\text { Status } \\
\text { dalam } \\
\text { Keluarga } \\
\end{array}$ & $\begin{array}{l}\text { Status } \\
\text { Pernikahan }\end{array}$ & $\begin{array}{l}\text { Pekerjaa } \\
\mathrm{n}\end{array}$ \\
\hline 1 & $\overline{A G}$ & R1 & Islam & $\mathrm{L}$ & 43 & Suami & $\begin{array}{l}\text { Nikah } \\
\text { Secara } \\
\text { Islam }\end{array}$ & $\begin{array}{l}\text { Wirausa } \\
\text { ha }\end{array}$ \\
\hline 2 & MA & $\mathrm{R} 1$ & Katolik & $\mathrm{P}$ & 31 & Istri & $\begin{array}{l}\text { Nikah } \\
\text { Secara } \\
\text { Islam }\end{array}$ & $\begin{array}{l}\text { Ibu } \\
\text { Rumah } \\
\text { Tangga }\end{array}$ \\
\hline 3 & SA & $\mathrm{R} 1$ & Islam & $\mathrm{P}$ & 13 & $\begin{array}{l}\text { Anak } \\
\text { Pertama }\end{array}$ & & Pelajar \\
\hline 4 & DD & $\mathrm{R} 1$ & Islam & $\mathrm{P}$ & 10 & $\begin{array}{l}\text { Anak } \\
\text { Kedua }\end{array}$ & & Pelajar \\
\hline 5 & RI & $\mathrm{R} 2$ & Islam & $\mathrm{L}$ & 39 & Suami & Nikah Siri & $\begin{array}{l}\text { Pegawai } \\
\text { Swasta }\end{array}$ \\
\hline 6 & RM & R2 & Kristen & $\mathrm{P}$ & 35 & Istri & Nikah Siri & $\begin{array}{l}\text { Ibu } \\
\text { Rumah } \\
\text { Tangga }\end{array}$ \\
\hline 7 & IS & $\mathrm{R} 2$ & Islam & $\mathrm{L}$ & 15 & Anak & & Pelajar \\
\hline 8 & $\mathrm{BO}$ & R3 & Islam & $\mathrm{L}$ & 52 & Suami & Nikah Siri & PNS \\
\hline 9 & TA & R3 & Katolik & $\mathrm{P}$ & 45 & Istri & Nikah Siri & PNS \\
\hline 10 & $\mathrm{HN}$ & R3 & Katolik & $\mathrm{L}$ & 20 & Anak & & Pelajar \\
\hline
\end{tabular}

\footnotetext{
${ }^{9}$ Sugiyono Sugiyono, Metodologi Penelitian (Bandung: CV Alfabeta, 2000).

${ }^{10}$ Sugiyono.
} 


\begin{tabular}{|c|c|c|c|c|c|c|c|c|}
\hline 11 & $\mathrm{AT}$ & $\mathrm{R} 3$ & Katolik & $\mathrm{L}$ & 15 & $\begin{array}{l}\text { Pertama } \\
\text { Anak } \\
\text { Kedua }\end{array}$ & \multirow{4}{*}{$\begin{array}{l}\text { Nikah } \\
\text { secara islam } \\
\text { Nikah } \\
\text { secara islam }\end{array}$} & Pelajar \\
\hline 12 & HY & $\mathrm{R} 4$ & Kristen & $\mathrm{L}$ & 62 & Suami & & $\begin{array}{l}\text { Karyawa } \\
\text { n Swasta }\end{array}$ \\
\hline 13 & TI & $\mathrm{R} 4$ & Islam & $\mathrm{P}$ & 39 & Istri & & Swasta \\
\hline 14 & VA & $\mathrm{R} 4$ & Islam & $\mathrm{P}$ & 25 & $\begin{array}{l}\text { Anak } \\
\text { pertama }\end{array}$ & & Pelajar \\
\hline 15 & $\mathrm{FE}$ & $\mathrm{R} 4$ & Islam & $\mathrm{L}$ & 16 & $\begin{array}{l}\text { Anak } \\
\text { kedua }\end{array}$ & \multirow{6}{*}{$\begin{array}{l}\text { Nikah } \\
\text { secara islam } \\
\text { Nikah } \\
\text { secara islam }\end{array}$} & Pelajar \\
\hline 16 & $\mathrm{KN}$ & $\mathrm{R} 4$ & Islam & $\mathrm{L}$ & 14 & $\begin{array}{l}\text { Anak } \\
\text { ketiga }\end{array}$ & & Pelajar \\
\hline 17 & $\mathrm{TK}$ & $\mathrm{R} 5$ & Islam & $\mathrm{L}$ & 41 & Suami & & Swasta \\
\hline 18 & AI & $\mathrm{R} 5$ & Islam & $\mathrm{P}$ & 43 & Istri & & Swasta \\
\hline 19 & $\mathrm{MO}$ & R5 & Islam & $\mathrm{L}$ & 18 & $\begin{array}{l}\text { Anak } \\
\text { pertama }\end{array}$ & & Pelajar \\
\hline 20 & $\mathrm{FO}$ & R5 & Islam & $\mathrm{P}$ & 9 & $\begin{array}{l}\text { Anak } \\
\text { kedua }\end{array}$ & & Pelajar \\
\hline
\end{tabular}

Keterangan: $\mathrm{R}=$ Informan, $\mathrm{L}=$ Laki-laki, $\mathrm{P}=$ Perempuan

\section{Kondisi Keluarga}

Kondisi keluarga R1, status pernikahan keluarga ini adalah pernikahan secara Islam yang berdasarkan kesepakatan dan kesediaan kedua belah pihak. Adapun kondisi agama setelah menikah sang istri kembali kepada agama Katolik. Walaupun sang istri kembali kepada agamanya, namun berdasarkan kesepakan awal sebelum menikah bahwa di kemudian hari anak harus memeluk agama Islam dan itu ditandai dengan akta kelahiran. $^{11}$

Kondisi keluarga R2, status pernikahan keluarga ini adalah pernikahan sirri. Kedua belah pihak baru saling mengetahui agama masing-masing bahwa calon suami beragama Islam dan calon istri beragama Kristen menjelang pernikahan. Pada awal pernikahan keduanya tidak membuat kesepakatan tentang agama anak dan kedua belah pihak menjalani kehidupan secara alami serta menyerahkan semua urusan agama kepada sang anak. ${ }^{12}$

Kondisi keluarga R3, status pernikahan keluarga ini adalah pernikahan sirri. Pernikahan keduanya disahkan oleh masing-masing pemuka agama. Dari pihak suami dinikahkan dan disahkan oleh seorang ustadz dan dari pihak istri dinikahkan dan disahkan oleh pendeta. Dalam kehidupan sehari-hari keduanya menjalankan aktifitas

\footnotetext{
${ }^{11}$ Wawancara dengan AG

${ }^{12}$ Wawancara dengan RI
} 
ibadah sesuai dengan keyakinan masing-masing secara rukun dan penuh toleransi. Berkaitan dengan agama anak, sebenarnya sang ayah menginginkan anaknya memeluk agama Islam, begitu pula sang ibu, namun untuk menjaga keharmonisan dan kerukunan dalam keluarga ini, sang ayah merelakan anak-anaknya mengikuti pendidikan agama dari sang ibu yaitu agama Katolik. ${ }^{13}$

Kondisi keluarga R4, status pernikahan keluarga ini adalah pernikahan secara Islam. Namun seiring berjalannya waktu sang suami kembali kepada agama asal (Kristen). Dalam kehidupan sehari-hari keduanya menjalankan aktifitas ibadah sesuai dengan keyakinan masing-masing secara rukun dan penuh toleransi. Adapun tentang agama anak mereka bersikap demokratis yaitu menyerahkan keputusan sepenuhnya kepada anak. ${ }^{14}$

Kondisi keluarga R5, status pernikahan keluarga ini adalah pernikahan Islam, namun dalam perjalanan hidupnya sang istri kembali kepada agama Kristen. ${ }^{15}$ Keluarga ini hidup bersama dengan mertua yang beragama Kristen, sehingga peneliti melihat bahwa kondisi demikian sangat berpengaruh terhadap pendidikan agama anak. Namun pada hakikatnya antara suami dan istri bersikap demokratis terhadap agama anak. Dengan artian, mereka menyerahkan keputusan sepenuhnya kepada sang anak, namun untuk saat ini kedua anaknya menjalankan aktifitas keagamaan secara Kristen mengikuti kebiasaan kakek dan neneknya dalam segala aktivitas, di samping itu peran ibu sangat besar pengaruhnya dalam menentukan pendidikan agama.

Dalam kehidupan manusia, agama merupakan salah satu yang paling penting. ${ }^{16}$ Diakui atau tidak, sesungguhnya manusia sangatlah membutuhkan agama untuk menjadi pedoman hidup. Tidak hanya pada masa-masa primitif sewaktu ilmu pengetahuan belum berkembang tetapi juga di zaman modern saat ini, saat ilmu dan teknologi telah maju begitu pesat. Setelah dilakukan wawancara, penulis mengambil suatu kesimpulan bahwa semua informan setuju dengan pentingya pendidikan agama Islam untuk anak meskipun mereka memiliki keyakinan agama yang berbeda.

\section{Problem yang dihadapi Orang Tua}

Pada bagian ini akan dijelaskan masalah-masalah yang dihadapi oleh orang tua saat mendidik anak mereka dengan cara Islam. Secara umum penulis dapat

\footnotetext{
${ }^{13}$ Wawancara dengan BO

${ }^{14}$ Wawancara dengan TA

${ }^{15}$ Wawancara dengan TI

${ }^{16}$ Agus M. Hardjana, Religiositas, Agama, dan Spiritualitas (Kanisius, 2005).
} 
menerangkan lima masalah yang dihadapi orang tua dalam penikahan beda agama untuk mendidik anak mereka.

1. Peran Ibu dalam Keberagamaan Anak Lebih Dominasi

Ada temuan menarik yang penulis dapat terkait dengan keterangan di atas tentang kondisi pendidikan keagamaan bagi anak, keberagamaan ibu lebih berperan dari pada keberagamaan ayah dalam penentuan agama pada anak. Dari deskripsi kondisi keluarga informan, dapat dilihat bahwa agama anak mengikuti agama ibu. Keadaan ini terjadi pada pasangan keluarga yang tidak melakukan perjanjian mengikat tentang agama anak, atau adanya perjanjian tetapi anak memiliki kebebasan dalam memilih agama.

Hal ini dapat terjadi karena ruang komunikasi dan interaksi antara ibu dengan anak lebih banyak dibandingkan antara ayah dan anak. Dominasi sosok ibu tak dapat dipisahkan dari banyaknya waktu yang dihabiskan untuk berinteraksi dengan anakanaknya. Pada salah satu keluarga pernikahan beda agama, sang ibu beragama Katolik dan ayah beragama Islam, sehingga cukup sulit bagi ayah untuk menerapkan pendidikan agama Islam pada anaknya. Pada akhirnya, anak akan lebih banyak menghabiskan waktu dengan ibunya dengan penanaman nilai-nilai pendidikan dalam agama katolik.

2. Sibuk Bekerja

Dari beberapa informan yang ada dalam penelitian ini, penulis menemukan salah satu informan yang mengaku mempunyai aktifitas di luar yang begitu padat sehingga tidak mempunyai waktu untuk mengajarkan pendidikan agama Islam kepada anak dan sang istri yang berada di rumah beragama Katolik.

3. Tidak adanya kesepakatan awal tentang agama anak

Pada pasangan yang tidak membuat kesepakatan tentang apa agama anak kelak ditemukan ada kecenderungan untuk menarik anak dalam agamanya masing-masing. Ada yang bersikap terbuka dan ada pula sebaliknya. Sikap terbuka diwujudkan dalam bentuk pelajaran agama dari kedua agama orangtua yang beda agama. Di mana setelah dewasa, anak diperbolehkan menentukan agamanya sendiri. Sementara yang tidak terbuka, cenderung dapat menimbulkan konflik dalam keluarga.

4. Pengetahuan Agama yang terbatas

Pada pasangan yang tidak terlalu kuat dalam beragama mempunyai dampak terhadap persepsi anak tentang agama mirip sebagaimana orangtuanya. Tingkat keberagamaan orang tua ini berdampak pada praktik-praktik keagamaan yang 
dilakukan anak. Anak cenderung tidak dididik dengan basis agama tertentu karena orang tua tidak memiliki pemahaman yang cukup dalam memberikan pendidikan agama pada anak.

\section{Terisolasi}

Adanya rasa terisolasi dari masyarakat beragama yang dikarenakan pernikahan beda agama belum mendapat tempat di Indonesia. Ulama dalam agama masing-masing banyak menyerukan dilarangnya pernikahan antar agama. Bahkan, beberapa ulama tegas mengatakan bahwa penikahan beda agama adalah suatu perbuatan zina. Hal ini yang menyebabkan ada rasa bersalah pada pasangan menikah beda agama dan merasa perlu mengisolasi dari pembicaraan tentang agama. Satu kasus terjadi dari informan peneliti, yaitu sang istri merasa malu untuk mengantar atau menemani anak ikut kegiatan keagamaan seperti TPA.

\section{Problem yang dihadapi Anak}

Pada bagian ini akan dijelaskan masalah-masalah yang dihadapi oleh anak dalam pernikahan beda agama. Penulis menerangkan tiga masalah yang dihadapi anak dalam penikahan beda agama.

1. Kebingungan

Perasaan bingung itu terjadi ketika ia menghadapi perbedaan agama orang tuanya. Di lain waktu ia pergi dengan sang ayah ke masjid dan terkadang bersama sang ibu ke gereja. Problem seperti itu akan berdampak buruk bagi perkembangan psikologi anak. Terlebih lagi jika anak mempunyai sifat kritis terhadap segala hal menjadikan ia semakin bingung. Terlebih lagi tidak ada komunikasi yang efektif dengan orang tua berakibat anak memikul beban psikologi yang sangat berat. Di mana seharusnya ia mengadu segala keluhan dan cerita kepada orang tua namun malah perbedaan itu terjadi pada orang tuanya dan ia semakin bingung harus menyampaikan kepada siapa. Dampak buruk lainnya adalah anak bisa menjadi takut untuk memilih agama, karena sesuai yang ia dapat setiap orang membenarkana agamanya, lantas agama mana yang harus ia anut. Jika anak-anak yang mengalami hal tersebut tidak memperoleh bantuan, maka akan mengidap masalah-masalah emosional yang akan terus berkembang.

2. Kurang percaya diri

Banyak hal yang menyebabkan anak merasa kurang percaya diri dengan temannya baik di sekolah maupun di lingkungan tempat ia bermain. Salah satu 
tindakan yang dilakukan orang tua adalah melarang dan membatasi kegiatan anak atau dengan artian ada paksaan orang tua terhadap anak. Sebagai contoh seperti yang terjadi dalam keluarga informan yang peneliti temukan, sang anak tidak boleh mengikuti kegiatan di masjid, di mana pada dasarnya mayoritas masyarakat yang hidup di lingkungan tersebut beragama Islam. Dengan demikian, rasa kurang percaya diri itu akan muncul seiring larangan dari orang tuanya yang selalu disampaikan kepada sang anak. Akhirnya anak tidak percaya diri dengan kemampuan yang ia miliki. Hal ini tidak hanya terjadi di lingkungannya, tetapi di sekolah pun ia akan merasa kurang percaya diri dengan teman-temannya karena di sekolah ia banyak bergaul dengan non muslim karena sekolahnya berbasis kristen.

Perbedaan agama sangat memengaruhi pergaulan anak, karena setiap anak yang memiliki kelompok bermain yang mempunyai banyak persamaan salah satunya adalah agama. Anak akan memilah-milah dengan siapa ia akan bermain dan permainan seperti apa yang akan dilakukannya. Tidak jarang dalam setiap komunikasi sang anak selalu memceritakan apa yang ia alami dan rasakan kepada teman-temannya. Seperti pendidikan keagamaan yang didapat di rumah. Anak yang mendapat bimbingan penuh dari segi keagamaan, perkataan dan tingkah lakunya didominasi oleh ajaran-ajaran agama. Seperti salah satu dari kelompok bermain tersebut menyampaikan kepada teman-temannya bahwa setiap ia akan melakukan kegiatan orang tuanya mewajibkan untuk membaca basmallah dan setelah selesai melakukan kegiatan apapun harus diakhiri dengan ucapan hamdalah. Ketika hal itu ia sampaikan kepada teman bermainnya, serentak teman-temannya yang seagama menjawab demikian juga yang diajarkan orang tuaku. Ketika kelompok bermain ini menemukan salah satu temannya tidak melakukan seperti yang ia lakukan dalam hidupnya mereka akan meremehkan bahkan akan mengolok-olok temannya. Akhirnya ia merasa tidak nyaman dalam kelompok tersebut karena ia berbeda agama.

3. Sikap Apatis terhadap Agama. ${ }^{17}$

Bukan tidak mungkin kebingungan yang dialami oleh anak dari pengajaran agama yang berbeda dari kedua orang tuanya memicu sikap apatis anak terhadap agama. Kasih sayang dan perhatian merupakan modal utama bagi para orang tua untuk mendidik anaknya. Mendapatkan perhatian dan kasih sayang merupakan hak

17 Apatis: Acuh tak acuh, tidak peduli, masa bodoh. Lihat, Pusat Pembinaan dan Pengembangan Bahasa, Kamus Besar Bahasa Indonesia, (Jakarta: Balai Pustaka, 2008). 
setiap anak. Tanpa disadari orang tua bahwa setiap anak memiliki berbagai karakter yang tidak baik untuk perkembangan kepribadiannya. ${ }^{18}$ Hal itu bisa saja terjadi karena kedua orang tua tidak memiliki agama yang kuat, sehingga anak tidak mendapat bimbingan dari kedua orang tuanya. Di sisi lain keduanya tidak peduli dengan pendidikan keagamaan. Ditambah lagi latar belakang keagamaan orang tua yang berbeda mengakibatkan kebingungan pada anak yang memicu munculnya sikap apatis anak terhadap agama. Faktor lain yang menyebabkan anak memiliki sikap apatis adalah karena orang tua yang mempercayakan pendidikan keagamaan sepenuhnya kepada pendidikan formal sehingga orang tua tidak lagi memerhatikan pendidikan agama anak.

\section{Pengaruh Luar yang Menambah Masalah}

Selain problem yang dihadapi oleh orang tua dan anak, penulis menampilkan masalah lain atau faktor eksternal yang dapat menambah problematika dalam pernikahan beda agama.

1. Lingkungan.

Menurut Syureich, lingkungan secara signifikan memengaruhi sikap dan perilaku seseorang, terutama pada anak. Tidak dapat diabaikan pengaruh lingkungan pergaulannya. Seseorang menjadi muslim atau tidak hal ini sangat ditentukan oleh lingkungan sosialnya. Apabila lingkungan sosialnya mayoritas Islam maka seseorang bisa menjadi Islam dan demikian sebaliknya. Dapat dikatakan bahwa lingkungan masyarakat di mana seseorang tinggal dapat menjadikan orang itu beriman atau tidak. ${ }^{19}$ Thalib mengatakan bahwa orang tua harus selalu memantau lingkungan pergaulan anak, terutama dapat memperhatikan teman-teman anaknya, karena anak-anak usia dini telah dapat bergaul dengan orang-orang di luar lingkungan keluarganya. Melalui pergaulan ini mereka bisa mengembangkan kemampuan sosial dan kebutuhan berhubungan dengan orang lain. ${ }^{20}$ Untuk itu orang tua wajib menaruh perhatian dengan siapa mereka bergaul. Karena teman bergaul dapat memberikan pengaruh pada kepribadian anak-anaknya.

\footnotetext{
18 Muhammad Yusuf, "Pendidikan Karakter pada Anak Usia Dini Perspektif Pendidikan Islam," Elementary: Jurnal Ilmiah Pendidikan Dasar 2, no. 1 (2017): 13-18.

19 Faza Choridatul Arifa, "Strategi pembentukan karakter religius di SD Negeri Wonokerto I Malang” (PhD Thesis, Universitas Is lam Negeri Maulana Malik Ibrahim, 2018).

20 Muhammad Thalib dan Khumaidi Ilyas, 40 tanggung jawab orang tua terhadap anak (Irsyad Baitus Salam (IBS), 1995).
} 
2. Media Elektronik (Televisi, smartphone, dan sejenisnya)

Televisi telah menjadi salah satu alat yang begitu efektif untuk mengubah perilaku seseorang. Hal ini terjadi karena televisi ada hampir di setiap rumah. Orangorang banyak menghabiskan waktu mereka untuk menonton televisi. Tidak ada bedanya dengan anak-anak. Anak-anak memiliki acara mereka sendiri seperti film kartun dan petualangan anak-anak. Adakalanya siaran televisi juga menyiarkan siaran yang tidak layak untuk ditonton oleh anak-anak.

Sama halnya dengan smartphone, saat ini, anak-anak hampir tidak terpisahkan dari telepon pintar. Hal ini disebabkan oleh apapun yang mereka ingin lihat dapat ditemui di telepon pintar mereka. Mereka bisa mengakses youtube, instagram, twitter, facebook, dan lainnya.

3. Komputer

Komputer bisa membantu anak belajar. Banyak anak prasekolah belajar membaca, berhitung dengan menggunakan komputer. Mereka juga bisa mengikuti perkembangan teknologi dengan teratur menggunakan komputer. Namun, seperti juga terlalu banyak menonton televisi, terlalu sering menggunakan komputer juga menimbulkan hal yang serius. Anak usia pra sekolah semestinya belajar berinteraksi secara sosial, dan interaksi dengan komputer tidak memungkinkan anak bercakapcakap atau bermain dengan anak lain. Peneliti melihat bahwa anak yang banyak berinteraksi dengan komputer pada masa usia pra sekolah, kelak mengalami kesulitan menyesuaikan diri dalam berinteraksi dengan anak lain baik di lingkungan bermain ataupun lingkungan sekolah. Sehingga hal ini juga berpengaruh terhadap pendidikan agama anak. Di mana anak bisa belajar agama dari lingkungannya akan tetapi karena sibuk berinteraksi dengan komputer sehingga tidak ada pengaruh yang didapatkan dari lingkungan. ${ }^{21}$

4. Pengaruh Pihak keluarga Bapak/Ibu.

Anak yang lahir dalam keluarga beda agama memiliki dua keluarga dengan dua agama berbeda, dari pihak keluar Bapak dan pihak keluarga Ibu. Keluarga besar dari pihak orang tua mereka juga sangat memengaruhi dalam memilih agama untuk anaknya. Anak yang dekat dengan keluarga ayah kemungkinan akan memilih agama yang dianut ayahnya, begitu juga sebaliknya.

${ }^{21}$ Tanja van der Lippe, Annet Jager, dan Yvonne Kops, "Combination Pressure: The Paid WorkFamily Balance of Men and Women in European Countries," Acta Sociologica 49, no. 3 (1 September 2006): 303-19, https://doi.org/10.1177/0001699306067711. 
Berdasarkan temuan penulis, pihak keluarga dari ibu atau ayah seringkali berupaya untuk ikut dalam menentukan pendidikan agama yang dianggap baik untuk anak. Upaya ini kadang menimbulkan konflik yang mengakibatkan rusaknya persaudaraan dan toleransi antar kedua keluarga.

\section{Aspek Positif Dalam Pendidikan Agama Anak dari Perkawinan Beda Agama}

Meskipun banyak problematika yang dihadapi oleh ana dalam keluarga dari perkawinan beda agama namun penulis dapat melihat beberapa aspek positif. Berikut dua aspek positif yang dapat dipetik oleh anak dari perkawinan beda agama dalam konteks pendidikan agama yang diperolehnya dalam keluarga.

1. Memiliki pengetahuan dasar dalam perbandingan agama

Anak dalam pernikahan beda agama memiliki pengetahuan agama selain agama yang dipeluknya. Adanya perbedaan agama dalam rumahnya sangat memungkinkan bagi anak untuk memiliki kemampuan dalam membandingkan agama-agama yang dianut oleh kedua orang tuanya. Anak sedikit banyak memahami atau bahkan mengartikulasikan konsep agama, teologi, ibadah dua agama orang tuanya. Hal ini cukup berbeda dengan anak yang dilahirkan dan dibesarkan pada orang tua yang seagama.

2. Toleran memandang perbedaan agama

Toleransi merupakan hal terpenting yang harus dilakukan dari kasus perkawinan beda agama. Untuk menjaga persatuan, maka diperlukan sikap toleran. ${ }^{22}$ Beberapa sikap toleransi yang dimiliki dapat dilihat adanya kesepakatan untuk tidak memasang simbol agama tertentu di rumah, menghormati anggota keluarga yang menjalankan ibadah sesuai dengan agamanya.

\section{Penutup}

Berdasarkan hasil penelitian dapat disimpulkan bahwa problem yang dihadapi orangtua beda agama terhadap proses pendidikan agama Islam anak adalah pendidikan didominasi oleh sang ibu, orang tua sibuk dalam pekerjaannya, pengetahuan agama yang terbatas, dan orang tua beda agama yang tidak melakukan perjanjian mengenai apa

22 Toleran: bersifat atau bersikap menenggang (menghargai, membiarkan, membolehkan), Pendirian (pendapat, pandangan, kepercayaan, kebiasaan, dan kelakuan) yang berbedah atau bertentangan dengan pendirian sendiri. Lihat, Pusat Pembinaan dan Pengembangan Bahasa, Kamus Besar Bahasa Indonesia, (Jakarta: Balai Pustaka, 2008) 
agama anak mereka kelak. Sedangkan problem yang dihadapi anak adalah kebingungan, kurang percaya diri, dan sikap apatis. Selain itu, ada aspek positif dapat diambil dari pernikahan beda agama yakni anak memiliki pengetahuan dasar perbandingan agama dan anak menjadi lebih toleran dalam memandang perbedaan agama.

\section{Daftar Rujukan}

Arini, Aida, and Halida Umami. "Pengembangan Pembelajaran Pendidikan Agama Islam Melalui Pembelajaran Konstruktivistik Dan Sosiokultural'. Indonesian Journal of Islamic Education Studies (IJIES) 2, no 2 (2019): 104-14. https://doi.org/10.33367/ijies.v2i2.845.

Arifa, Faza Choridatul. "Strategi pembentukan karakter religius di SD Negeri Wonokerto I Malang." PhD Thesis, Universitas Islam Negeri Maulana Malik Ibrahim, 2018.

Dahwal, Sirman. "Hukum perkawinan beda agama dalam teori dan praktiknya di Indonesia," 2016.

Hardjana, Agus M. Religiositas, Agama, dan Spiritualitas. Kanisius, 2005.

Hasan, Maimunah. "Pendidikan anak usia dini." Yogyakarta: Diva, 2009.

Hutapea, Bonar. "Dinamika Penyesuaian Suami-Istri dalam Perkawinan Berbeda Agama (the Dynamics of Marital Adjustment in the Interfaith Marriage)." Sosio Konsepsia 16, no. 1 (2017): 101-122.

Indonesia, Tim Penyusun Kamus Besar Bahasa. Kamus besar bahasa Indonesia. Jakarta: Balai Pustaka,2008.

Lippe, Tanja van der, Annet Jager, dan Yvonne Kops. "Combination Pressure: The Paid Work-Family Balance of Men and Women in European Countries." Acta Sociologica 49, no. 3 (1 September 2006): 303-19. https://doi.org/10.1177/0001699306067711.

Makalew, Jane. "Akibat hukum dari perkawinan beda agama di Indonesia." Lex Privatum 1, no. 2 (2013).

Yusuf, Muhammad. "Pendidikan Karakter pada Anak Usia Dini Perspektif Pendidikan Islam.” Elementary: Jurnal Ilmiah Pendidikan Dasar 2, no. 1 (2017): 13-18.

Pratiwi, Hildha. "Hubungan antara Dukungan Sosial Keluarga dengan Kepuasan Perkawinan Pada Istri." Undergraduate thesis, Univeristas Surabaya, 2014. http://digilib.ubaya.ac.id/pustaka.php/240188.

Rimm, Sylvia B. Mendidik dan menerapkan disiplin pada anak prasekolah: pola asuh anak masa kini. Gramedia Pustaka Utama, 2003.

Saadah, Ulul Ilmawanis. "Nilai-Nilai Pendidikan Islam Dalam Upacara Syukuran Ngapati Di Desa Kwayangan Kecamatan Kedungwuni Kabupaten Pekalongan.” $\mathrm{PhD}$ Thesis, STAIN Pekalongan, 2014.

Strauss, Anselm, dan Juliet Corbin. "Dasar-dasar penelitian kualitatif." Yogyakarta: Pustaka Pelajar, 2003.

Sugiyono, Sugiyono. Metodologi Penelitian. Bandung: CV Alfabeta, 2000. 
Problematika Pendidikan Agama..., M. Yusuf,Ani Susilawati,Aprezo PM

Thalib, Muhammad, dan Khumaidi Ilyas. 40 tanggung jawab orang tua terhadap anak. Irsyad Baitus Salam (IBS), 1995.

Waharman, Waharman. "Peran Orang Tua Dalam Pertumbuhan Spiritualitas Anak: Sebuah Studi Eksegetis Efesus 6: 1-4.” Manna Rafflesia 4, no. 2 (2018): 116129.

Wahyuni, Sri. "Kontroversi Perkawinan Beda Agama di Indonesia." Jurnal Hukum Islam, 2016. 